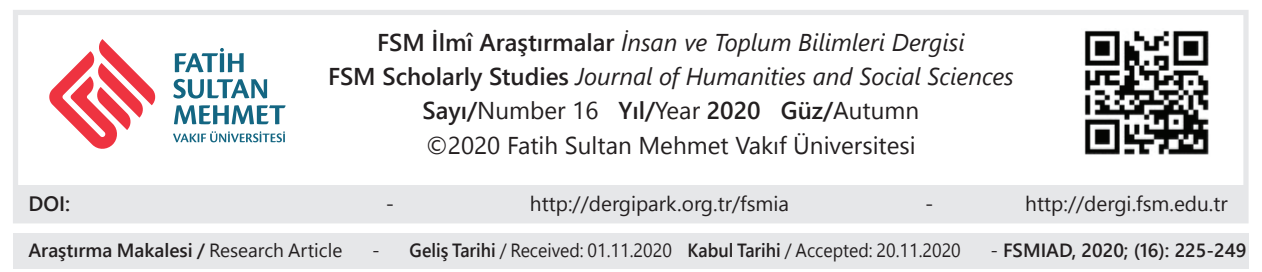

\title{
Irak Selçuklu, Abbâsî Hilâfeti ve Büyük Selçuklu Üçgeninde Kudretli Hille Emîri: Dübeys B. Sadaka \\ Pınar Kaya Tan*
}

\section{Öz}

Sultan Sencer'in (512-552/1119-1157), Sâve Savaşı'ndan sonra Büyük Sultan sıfatıyla topraklarının batısını yeğeni Mahmûd b. Muhammed Tapar'ın idâresine bırakmasıyla Selçukluların yeni bir kolu Irak Selçuklu Devleti kurulmuştur. Bununla birlikte tesis edilen yeni devlet içinde sultan ve melikler arasında taht mücadelelerinin güçlü emîr ve atabeglerin etkisiyle mütemadiyen devam ettiği görülmektedir. Hille Emîri Seyfüddevle Sadaka b. Mezyed'in oğlu olan Dübeys b. Sadaka (ö. 529/1135), Büyük Selçuklu Sultanı Muhammed Tapar'ın (498-511/1105-1118) vefatından sonra Mezyedî Ailesi’nin hüküm sürdüğü Hille ve civarında hâkimiyetini tesis etmeyi başarmıştır. Irak Selçuklu Devleti'nin içinde bulunduğu durumu yakından takip eden Dübeys b. Sadaka, Sultan Mahmûd b. Muhammed Tapar döneminde (511-525/1118-1131) gerçekleşen şehzade isyanlarını körükleyerek nüfuzunu, hâkimiyet sahasını genişletmeye çaba sarf etmiştir. Ayrıca onun, babasının ölümünden dolayı sorumlu tuttuğu Abbâsîlere ve Selçuklulara karşı düşmanlığını gizlemediği görülmektedir. Dübeys b. Sadaka, emîrliğini ayakta tutabilmek için bölgede etkisi olan askerî güce sahip pek çok kumandanla, Arap

* $\quad$ Dr. Öğr. Üyesi, Kırklareli Üniversitesi Fen-Edebiyat Fakültesi Tarih Bölümü Ortaçağ Tarihi Anabilim Dal1, Kırklareli/Türkiye, pinarkaya@klu.edu.tr, orcid.org/0000-0002-7025-399X 
topluluklarıyla hatta Haçlılarla dahi ittifak kurmaktan çekinmemiştir. Abbâsî Hilâfeti ve Irak Selçuklu Devleti topraklarını Hille'deki emîrliğine mensup olanlarla birlikte her bulduğu firsatta yağmalamış, ağır tahribatlarda bulunmuştur. Bu çalışma Irak Selçuklu Sultanı Mahmûd b. Muhammed Tapar döneminde Dübeys b. Sadaka'nın oldukça yoğun olan faaliyetlerini, Irak Selçukluları, Abbâsîler ve Büyük Selçuklular ile münasebetlerini kaynakların verdiği bilgiler ışığında ele almaktadır.

Anahtar Kelimeler: Dübeys b. Sadaka, Selçuklular, Sultan Mahmûd b. Muhammed Tapar, Müsterşid Billâh, Sultan Sencer.

\section{Dubays B. Sadaḳa: The Powerful Amīr of Hilla in the Triangle of the 'Irāk Saldjūḳid State, the Abbasīd Caliphate and the Great Saldjūkeid State}

\section{Abstract}

After Sultān Sandjar (512-552/1119-1157), ceded the west of the lands to the rule of his nephew Mạ̣mūd b. Muḥammad Tapar as the Supreme Sultān following the battle of Sāwa, a new branch of the Saldjūḳids, Irāḳ Saldjūḳid State was established. Regardless, it is seen that the struggle for the throne between the sultān and the maliks continued within the new state with the influence of strong amīrs and atabegs. Dubays b. Sadaka (d. 529/1135), son of Sayf al-Dawla Sadaḳa b. Mazyad, the amīr of has managed to establish his reign in Hilla and its vicinity, which was ruled by Mazyadid Family after the death of Great Saldjūḳid Sulțān Muḥammad Tapar (498-511/1105-1118). Closely monitoring the state of the 'Irāḳ Saldjūḳid State, Dubays b. Sadaḳa has made efforts to expans his influence and area of dominance by inciting prince revolts that took place in the reign of Sulțān Maḥmūd b. Muhammad Tapar (511-525/1118-1131). Furthermore, it is seen that he does not hide his enmity towards the Abbasīds and the Saldjūkids he held responsible for the death of his father. In order to keep his amīrate intact, Dubays b. Sadaka did not refrain from making alliances with many commanders in the area who have military strength, Arab communities and even with the crusaders. He has raided and heavily destroyed the lands of Abbasīd Caliphate and 'Irāk Saldjūḳid State at every opportunity with the subjects of his amīrate in Hilla. This study discusses the activities of Dubays b. Sadaḳa, during the reign of Irāḳ Saldjūḳid Sulțān Mạ̣mūd b. Muhammad Tapar and his relations with 'Irāḳ Saldjūkids, Abbasīds and Great Saldjūkids in light of the information from the sources.

Keywords: Dubays b. Sadaḳa, Saldjūḳids, Sulțān Mạ̣mūd b. Muhammad Tapar, al-Mustarshid Bi'llāh, Sulțān Sandjar. 
IV. (X.) yüzyıldan itibaren Irak’taki bazı Arap kabileleri devlet kurma temayülü içerisine girince Mezyedîler de Hille ve Orta Irak’ta, Kûfe-Hît arasında kalan topraklarda bir emîrlik tesis etmişlerdi. ${ }^{1}$ Dübeys b. Sadaka, Hille² Emîri Seyfüddevle Sadaka b. Mezyed'in oğlu idi. Dübeys ve ailesi merkezî Irak'ta hüküm sürmüş olan Mezyedîlere (387-558/997-1163) mensuptu. Zaman içinde Mezyedîler, Büyük Selçuklu Sultanlarının hâkimiyetleri altına girmişlerdi. Seyfüddevle Sadaka b. Mezyed, 501 yılı Receb ayında (Mart 1108) başlangıçta ittifak hâlinde olduğu ve hatta Berkyaruk ile gerçekleşen taht mücadelesinde destek verdiği Büyük Selçuklu Sultanı Muhammed Tapar ile anlaşmazlığa düşmüş; sultan ile gerçekleşen muharebeyi kaybederek öldürülmüştü. ${ }^{3}$ Babası ile bu savaşa katılan Dübeys $b$. Sadaka ise derdest edilip sultan tarafından Bağdat'a götürülmüş, bağl1lık sözü alındıktan sonra da serbest bırakılmıştır. Herhangi bir isyan teşebbüsüne girişmemesi için Dübeys'in Mezyedî Ailesi'nin hüküm sürdüğü topraklar olan Hille'ye gitmesine izin verilmemişse de İbnü'l-Esîr'in (ö. 630/1233) kaydına göre; Sultan Muhammed Tapar'ın Dübeys b. Sadaka'ya çok iyi davrandığı ve birçok yeri ona iktâ ettiği zikredilmektedir. ${ }^{4}$ Dübeys ancak Muhammed Tapar'ın 511 (1118) yılındaki vefatından sonra Hille'ye dönebilmiştir. ${ }^{5}$ Bununla birlikte Dübeys b. Sadaka, 512 (1118-1119) yılında o sırada Büyük Selçuklu Devleti'nin başında olan Sultan Mahmûd'a müracaat ederek Hille'ye dönmeyi ve babasının hüküm sürdüğü topraklara vâli olarak tâyin edilmek istediğini bildirdi. Nitekim sultanın muvafakatıyla arzusuna kavuşarak uzun bir aradan sonra Hille'ye geri dönünce bölgede yaşayan Araplar, Kürtler kısa süre içerisinde Dübeys'in etrafında toplanmaya başladılar. Şanı gitgide yüceldi ve nâmı giderek yayıld1 ${ }^{6}$ Böy-

1 İmâdüddin Halîl, “Irak, III. Tarih”, DİA, XIX, s. 90; Abdülkerim Özaydın, "Mezyedîler”, DİA, XXIX, s. 550-551.

2 Hille, Kûfe ve Bağdat arasında yer alan Mezyedîlerin yaşadığı, devamlı alışveriş yapılan kalabalık çarşılarıyla meşhur büyük bir şehirdir. Bkz. İbn Havkal, Sûretü'l-ârz, X. Asır'da İslâm Coğrafyası, Türkçe trc. Ramazan Şeşen, İstanbul, 2014, s. 228; Yâkūt el-Hamevî, Mu cemü'l-büldân, II, nşr. Dâru Sâdır, Beyrut, 1397/1977, s. 294-295; Ebü'l-Fidâ, Takvîmü'l-büldân, Ebü'l-Fidâ Coğrafyası, Türkçe trc. Ramazan Şeşen, İstanbul, 2017, s. 249.

3 Azîmî, Târîhu'l Azîmî, Azîmî Tarihi: Selçuklularla İlgili Bölümler (H. 430-538=1038/391043/44), nşr. Ali Sevim, Ankara, 2006, s. 43; İbnü'l-Esîr, el-Kâmil fi 't-târih, İslâm Tarihi İbnü'l-Esîr, el-Kâmil fi 't-Tarih Tercümesi, X, Türkçe trc. Abdülkerim Özaydın, İstanbul, 1987, s. 353-360; Ebü'l-Fidâ, el-Muhtasar fí ahbâri'l-beşer, Târîhu Ebi'l-Fidâ, II, nşr. Mahmûd Deyyûb, Beyrut 1417/1997, s. 42.

4 a.g.e., X, s. 424.

5 Nadir Karakuş, "Hille'de Bir Bedevî Emîri: Dübeys b. Sadaka”, Marife, c. 18, say1 2, 2018, s. 373; Abdülkerim Özaydın, "Dübeys b. Sadaka", DİA, X, s. 14.

6 İbnü'l-Esîr, el-Kâmil, X, s. 424; Ebü'l-Fidâ, el-Muhtasar, II, s. 51; İbnü'l-Verdî, Tetimmetü'l Muhtasar fí ahbâri'l-beşer, II, nşr. Ahmed Rıf'at el-Bedrâvî, Beyrut, 1970, s. 40; İbn Kesîr, 
lelikle Hille'deki emîrliğinin başına geçen Dübeys b. Sadaka, Selçuklu melikleri arasında yaşanan husûmetlerden de istifade ederek nüfuzunu artırmak üzere harekete geçmeye başlayacaktı. Babasının Dübeys'e karşı yürüttüğü tavrı devam ettiremeyen ve Hille Emîri'nin ne kadar tehlikeli olabileceğini fark etmeyen Sultan Mahmûd ise yapmış olduğu hatasının menfî neticelerini yaşayarak öğrenecektir.

Büyük Selçuklu Sultanı olan Mahmûd tahta çıktıktan kısa bir süre sonra babası Sultan Muhammed döneminden beri itibar kazanmış Bağdat şahnesi ${ }^{7}$ Bihrûz el-Hâdim 'i ${ }^{8}$ azlederek Muhammed Tapar'ın da meşhur emîrlerinden olan Aksungur el-Porsukî'yi (ö. 520/1126) Bağdat şahneliğine tayin etti. Atamanın yapılmasında ise Bihrûz el-Hâdim'in güç kazanmasını istemeyen ve Aksungur el-Porsukî'yi destekleyerek her firsatta ona bağlılıklarını ifade eden emîrlerin oldukça büyük etkisi bulunmaktaydı. ${ }^{9}$ Emîrler muhtemelen yeni sultanın tahta çıkmış olduğu bir dönemde Irak'ta düzeni sağlamak adına güçlü bir şahsiyetin mevcudiyetine ihtiyaç duymaktaydılar. ${ }^{10}$ Kısa süre sonra Aksungur el-Porsukî, Sultan Mahmûd'un emri ile görevden alınarak yerine yine dönemin büyük emîrlerinden Mengüpars ${ }^{11}$ tayin edildi. Ancak Aksungur el-Porsukî azledilmekten dolayı rahatsızlık duyduğu için Sultan Mahmûd'un saltanatının henüz başlangıcında huzursuzluklar artar olmuştu.

Aksungur el-Porsukî, Mengüpars'in nâib olarak yolladığı üvey oğlunu Bağdat'a sokmamakla beraber Sultan Mahmûd'un teveccühüyle Hille'ye dönmüş olan Dübeys b. Sadaka ile 512 yılı Cemâziyelevvel ayında (Ağustos-Eylül 1118) karşı karşıya geldi. Aksungur'un Hille üzerine yürüyerek Dübeys'i oradan uzaklaştıracağı haberi yayılınca Dübeys, Araplar ve Kürtlerden müteşekkil büyük bir

el-Bidâye ve'n-Nihâye, el-Bidâye ve'n-Nihâye, Büyük İslâm Tarihi, Türkçe trc. Mehmet Keskin, XII, s. 346.

7 Bir şehir ya da bölgenin emniyet ve asayişinden sorumlu askerî vâli anlamına gelen şahne hakkında bkz. Abdülkerim Özaydın, "Büyük Selçuklularda Şahnelik Müessesesi ve Şahnelerin Taht Kavgalarındaki Rolü”, İsmail E. Erünsal'a Armağan, I, İstanbul, 2014, s. 477-504; Erdoğan Merçil, "Şahne", DİA, XXXVIII, s. 292-293.

8 Hayatı ve faaliyetleri hakkında bkz. Nevzat Keleş, "İnsanların En Kibarlarından: Selçukluların Bağdad Şahnesi Bihrûz el-Hâdim”, Tarih İncelemeleri Dergisi, c. XXX, sayı 2, 2015, s. 451477.

9 İbnü'l-Esîr, el-Kâmil, X, s. 424.

10 Alex Mallett, "The Life of Aq-Sunqur al-Bursuqi: Some Notes on Twelfth-Century Islamic History and Thirteenth-Century Muslim Historiography", Turkish Historical Review, c. 2, say1 1, 2011, s. 45.

11 Emîr Mengüpars'ın faaliyetleri hakkında bkz. Cihan Piyadeoğlu, "Büyük Selçuklular Döneminde Atabegler”, (Yayımlanmamış Yüksek Lisans Tezi), İstanbul Üniversitesi Sosyal Bilimler Enstitüsü, İstanbul, 1999, s. 80-82. 
ordu toplayarak onlara bol miktarda para ve silâh dağıttı. Mehmet Altay Köymen, Aksungur el-Porsukî'nin şahnelik meselesi ile ilgili olarak Mengüpars ile rekabet ederken birden Dübeys ile mücadele etmesindeki hedefin saptanamadığını; bunun ancak Aksungur'un Bağdat ve çevresinde tek başına hâkimiyet kurmak istemesiyle izah edilebileceğini belirtmektedir. Böylece Selçuklu hükümdarlarının arzu ve isteği dışında Türk hâkimiyetini kurmak isteyen bir kumandanla, Arap hâkimiyetini kurmak isteyen Dübeys arasındaki mücadele için hazırlıklar yapılmıştır. ${ }^{12}$

Bu esnada yaşanan karışıklıklardan istifade etmek isteyen Sultan Mahmûd'un kardeşi Melik Mes'ûd b. Muhammed Tapar ve atabegi Ay-aba Cüyûş (Çavuş) Beg' in ${ }^{13}$ tahtı ele geçirmek amacıyla yürüttükleri faaliyetler göze çarpmaktadır. Melik Mes'ûd, atabegi ile birlikte Musul'da bulundukları sırada maiyetlerinde bulunan emîrler sahip oldukları kuvvet sebebiyle kendilerine mâni olacak bir gücün olmadığını söyleyerek bu karışık ortamdan yararlanmalarını tavsiye ediyor; melik ve atabegini Irak'a yürümeleri yönünde teşvik ediyorlardı. Nihayetinde Melik Mes'ûd büyük bir orduyla harekete geçti. Aksungur el-Porsukî böylesine kalabalık kuvvetlerin Bağdat'a yaklaştıklarını haber alınca onlarla savaşmak ve şehre girmelerine engel olmak için Hille yakınlarında kurmuş olduğu karargâhını kaldırarak Melik Mes'ûd ve Ay-aba Cüyûş Beg'e doğru ilerlemeye başladı. Melik Mes'ûd ile Cüyûş Beg bunu haber alınca Emîr Kirbâvi'yi Aksungur el-Porsukî’ye göndererek barış talep ettiler. Amaçlarının mücadele hâlinde olduğu Hille Emîri Dübeys b. Sadaka'ya karşı ona yardım etmek olduğunu bildirerek Aksungur'u saflarına çekmek istediler. Böylece barış anlaşması yaptılar ve beraberce hareket etmeye başladılar. ${ }^{14}$ Öte yandan Emîr Mengüpars, Melik Mes' ûd'un isyanını bastırmak amacıyla harekete geçti. Melik Mes'ûd ve Atabeg Ay-aba Cüyûş ile işbirliği yapmış olan Aksungur el-Porsukî bu defa Mengüpars ile savaşmak üzere hazırlıklara başladı. Mengüpars bunu öğrenince tek başına savaşmayı göze alamayarak Dicle'yi geçip Dübeys b. Sadaka ile ittifak kurmaya karar verdi. Melik Mes'ûd ve Aksungur el-Porsukî'den çekinen Dübeys, meseleyi güzellikle hâlledip savaşa mâni olmak gayesiyle Mes'ûd ve atabegine, ayrica Aksungur el-Porsukî’ye hediyeler göndermişti fakat Mengüpars'ın kendisiyle ittifak etmek için geldiğini haber alınca onunla anlaşmayı tercih etti. Yapılan anlaşmaya göre iki taraf birbirlerine yardım edip destek olacaklardı. Dübeys ile Mengüpars birleşince Melik Mes'ûd, Ay-aba Cüyûş Beg ve Aksungur el-Porsukî onlara karş1

12 Mehmet Altay Köymen, Büyük Selçuklu İmparatorluğu Tarihi, İkinci İmparatorluk Devri, V, Ankara, 1991, s. 30, n. 1.

13 Piyadeoğlu, a.g.e., s. 87-95.

14 İbnü'l-Esîr, el-Kâmil, X, s. 428-429; Piyadeoğlu, a.g.e., s. 90. 
muharebe etmek üzere Medâin'e ${ }^{15}$ gittiler. Şehre vardıklarında ise rakiplerinin çok sayıda askere sahip olduğunu haber aldılar ve geri çekilmeye karar verdiler. Hatta dönerken de bölgeyi yağmalama faaliyetlerine giriştiler. ${ }^{16}$

Yaşananlar üzerine Halife el-Müsterşid ${ }^{17}$ (512-529/1118-1135), Melik Mes 'ûd ile Aksungur el-Porsukî’ye elçi göndererek bu durumu yadırgadığını bildirdi ve onlardan fesat çıkarmaktan vazgeçerek anlaşmaya varmalarını, durumu sulh ile çözmelerini istedi. Atabeg Ay-aba Cüyûş Beg, Melik Mes'ûd ile birlikte yaptıkları bu başarısız teşebbüs yüzünden Sultan Mahmûd'un tepkisini çekmek istememiş olacaktır ki sultana müracaat ederek sahip oldukları iktâlarının artırılmasını istemiş; sultan da kendisinin meşrû hükümdarlığını tanıdığını gösteren bu talepleri kabul etmiştir. ${ }^{18}$ Söz konusu uzlaşma üzerine Aksungur el-Porsukî müşkül duruma düşmüş, Irak'1 elde etme teşebbüsü başarısızlığa uğramış, birlikleri dağılmış ve kendisi de Melik Mes'ûd'un yanına gitmek zorunda kalmıştı. Mengüpars ise Bağdat şahneliğinde karar kılmışsa da çok geçmeden Sultan Mahmûd'un emri ile öldürülmüştür. ${ }^{19}$ Dübeys b. Sadaka ise babasının Derb-i Firûz'da bulunan evindeki hakkının iade edilmesi üzerine idâresi altındaki Hille'ye dönmüştür. ${ }^{20}$

Bu sırada Selçuklu tarihinde mühim bir husus vuku bulacak ve Selçukluların yeni bir kolu ortaya çıkacaktı. Büyük Selçuklu Sultanı olarak Mahmûd b. Muhammed Tapar'in Dübeys b. Sadaka ile olan münasebetleri bu şekilde iken taht iddiasında bulunan amcası Sencer, 2 Cemâziyelevvel 513'te (11 Ağustos 1119) Sâve'de yeğeni Mahmûd b. Muhammed Tapar'ı hezimete uğrattı. Yapılan muharebe sonrasında Sencer, Horasan'da yönetimini “Büyük Sultan” olarak devam ettirirken, ülkesinin batı topraklarını kardeşinin oğluna bırakarak Irak Selçuklu Devleti'nin başına Mahmûd b. Muhammed Tapar'ı getirdi. Bu çalışmanın konusu Dübeys b. Sadaka'nın bilhassa ilk Irak Selçuklu Sultanı dönemindeki siyasî

15 Medâin, Sâsânîlerin baş şehri olup Bağdat'’n $30 \mathrm{~km}$. güney doğusunda Dicle'nin iki yakasında kurulmuş yedi ayrı şehirden oluşur. Bkz. İbn Havkal, a.g.e., s. 227-228; Casim Avc1, "Medâin", DİA, XXVIII, s. 289-291.

16 İbnü'l-Esîr, el-Kâmil, X, s. 429; Hüseyin Kayhan, Irak Selçukluları, Konya, 2001, s. 38; Piyadeoğlu, a.g.e., s. 90-91.

17 Abbâsî Halifesi hakkında ayrıntılı bilgi için bkz. Osman Gazi Özgüdenli, "Selçuklu-Hilâfet Münasebetlerinde Bir Dönüm Noktas1: Halife el-Müsterşid'in Katli Meselesi”, Tarih Dergisi, say1 39, 2004, s. 1-36; Fatih Güzel, "Selçuklulara Başkaldıran İlk Halife: Müsterşid Billah (512-529/1118-1135)", İnsan ve Toplum Bilimleri Araştırmaları Dergisi (İtobiad), c. 8, say1 4, 2019, s. 3134-3151; Osman Gazi Özgüdenli, "Müsterşid-Billâh”, DİA, XXXII, s. 145-147.

18 İbnü'l-Esîr, el-Kâmil, X, s. 430; Köymen, a.g.e., V, s. 32.

19 İbnü'l-Esîr, el-Kâmil, X, s. 441-442; Piyadeoğlu, a.g.e., s. 82.

20 İbnü'l-Esîr, el-Kâmil, X, s. 429-430; Karakuş, a.g.m., Marife, c. 18, sayı 2, s. 375. 
faaliyetlerini, hâkimiyet sahasını genişletmek üzere girişmiş olduğu teşebbüslerini ortaya koymak ve Sultan Mahmûd dönemindeki Irak Selçuklu melikleriyle Dübeys'in ilişkilerini incelemektir. Şüphesiz Büyük Selçuklu Sultanı Sencer ve mezkûr dönemin Abbâsî Halifesi Müsterşid Billâh ile yaşanan hadiseler de Irak Selçukluları ile münasebetler kapsamında ele alınıp değerlendirilecektir.

Sâve Muharebesi'nden önce Hille'ye dönmüş olduğu anlaşılan Dübeys b. Sadaka, Sultan Sencer'in zaferinin ardından Abbâsî Halifesi'ne haber göndererek Bağdat'ta hutbenin Sencer adına okutulmasını istemişti. ${ }^{21}$ Dübeys'in muharebe esnasındaki faaliyetleri hakkında mâlûmata rastlamak mümkün olmamakla birlikte bölgede yaşanan gelişmelerden süratle haberdâr olduğu ve yeni sultanla iyi ilişkiler kurarak Irak’ta güçlü bir konuma sahip olmak istediği âşikardır.

Irak Selçuklu Devleti'nin tesis edilmesinden sonra 514 (1120-1121) yılında ise Dübeys b. Sadaka'nın küçük yaşta olan melikleri birbirlerine düşürerek yeniden güç elde etme hırsına kapıldığg görülmektedir. Bu amaç uğruna Atabeg Ay-aba Cüyûş Beg'e haberler göndererek atabegi sultanın kardeşi Melik Mes'ûd adına tahtı ele geçirmeye teşvik ediyordu. Ayrıca aralarında husumet bulunan Aksungur el-Porsukî'ye inanmamasını istiyor; Aksungur'un tevkif edilmesi için oldukça çaba sarf ediyordu. Aksungur el-Porsukî durumdan haberdâr olunca çareyi Irak Selçuklu Sultanı Mahmûd'un yanına gitmekte buldu. Sultan Mahmûd, Aksungur'u çok iyi karşıladı, mevkisini yükseltti, ona daha önemli vazifeler tevdî etti. Sultan Mahmûd, kardeşi Mes'ûd'a da mektup yazarak itaatkâr olması hâlinde lütuf ve ihsanda bulunacağını, aksi takdirde ise kendisini ağır bir şekilde cezalandıracağını bildirdi. Ancak tüm uyarılara rağmen Atabeg Ay-aba Cüyûş Beg, Mes'ûd adına hutbe okutup kapısında beş vakit nevbet çaldırarak onu sultan ilân etti. $^{22} \mathrm{Bu}$ durum bir atabegin küçük yaşta bir melik adına hüküm verip çıkarları doğrultusunda şehzadeyi kullandığını göstermesi bakımından önemlidir.

Nihayetinde taraflar Hemedan yakınlarındaki Esedâbâd' da karşılaşarak sabahın erken saatlerinden akşama kadar muharebe ettiler. Sultan Mahmûd'un ordusunun en ön saflarında Aksungur el-Porsukî mücadele etmiş ve savaşın kazanılmasında büyük oranda pay sahibi olmuştu. Melik Mes 'ûd'un askerleri hezimete uğradığı gibi ileri gelen kumandanlarından birçoğu esir düşmüştü. Hatta Melik Mes'ûd muharebeyi kaybettikten sonra kardeşi Sultan Mahmûd'dan emân dilemek istediyse de daha sonra emîrlerinin tavsiyeleri üzerine Musul'a gitmeyi

21 İbnü'l-Esîr, el-Kâmil, X, s. 438; Kayhan, a.g.e., s. 43.

22 İbnü'l-Esîr, el-Kâmil, X, s. 446-447; Ebü'l-Fidâ, el-Muhtasar, II, s. 53; Coşkun Alptekin, “Irak Selçukluları", Doğuştan Günümüze Büyük İslâm Tarihi (DGBİT), VII, İstanbul, 1988, s. 295296; Karakuş, a.g.m., Marife, c. 18, sayı 2, s. 375. 
ve Dübeys b. Sadaka ile birleşerek yeniden mücadele etmeyi uygun gördü. Bu durum üzerine Melik Mes'ûd'u, Sultan Mahmûd'a götürmekle görevli olan Aksungur el-Porsukî hızlı bir şekilde harekete geçerek Melik Mes'ûd'a yetişti. Ona kardeşi tarafından affedildiğini bildirdi ve Mes'ûd'u karargâha götürdü. Sultan Mahmûd ise askerlerine kardeşini karşılamalarını, sayg1 göstermelerini emretti. Irak Selçuklu Sultanı kabul merasimi (bâr-1 hâss) düzenleyerek Mes'ûd'u huzuruna kabul etti. İki kardeş kucaklaşıp ağladılar. ${ }^{23}$ Sultan Mahmûd, Melik Mes 'ûd'u ardından da atabegini affetmiş olsa da Musul'u Melik Mes'ûd'un elinden alarak muharebede büyük yararlılıklar gösteren Aksungur el-Porsukî'ye iktâ etmeyi de ihmâl etmedi. ${ }^{24}$

Sultan Mahmûd'a itaat arz etmeyen bir tek Dübeys b. Sadaka kalmıştı ve Hille Emîri, Irak bölgesini tahrip ederek yağmalamaya devam ediyordu. Mehmet Altay Köymen, Dübeys'in Selçuklu aleyhtarı siyasetinin iki temele dayandığını vurgulamaktadır:

1. Çoktan beri kaybedilen Arap nüfuzunu yeniden tesis etmek.

2. Babası Sadaka'nın hayatıyla ödediği siyasetini devam ettirerek öncelikle bütün Arapları, sonrasında kendi hânedanını ilgilendiren ananevî iki siyaseti takip etmek. ${ }^{25}$ Nitekim babasının intikamını almak isteği içinde olan Dübeys'in bu amaç doğrultusunda hareket ettiği tarihî hadiselerden de anlaşılmaktadır.

Dübeys, halifenin uyarılarına ve Sultan Mahmûd'un kendisine bir takım imtiyazlar vermesine rağmen tahribatlarına devam ediyor Bağdat ve çevresine yağmacılık, adam öldürme, bozgunculuk gibi hareketlerle korku salıyordu. Halife bu davranışları kınamış ve derhâl vazgeçmesini bildirmişse de Dübeys aksine bu defa Bağdat üzerine harekete geçti. 514 yılı Cemâzileyâhir'inde (Ağustos-Eylül 1120) şehre vardığında ordusuyla birlikte halifenin sarayının tam karşısında karargâhını kurdu. İçindeki kin ve öfkeyi ortaya koyarak vaktiyle babasının kesik başının şehirde dolaştırılıp teşhir edildiğini Müsterşid Billâh'a hatırlatarak tehditlerini sürdürdü. Dübeys'in faaliyetleri Bağdat halkını korku ve endişeye sevk etti. Halife, Sultan Mahmûd ile bozulan ilişkilerini düzeltebileceğini söyleyerek Dü-

23 İbnü'l-Cevzî, el-Muntazam fî târîhi 'l-mülûk ve'l-ümem, XVII, nşr. Muhammed Abdülkādir Ahmed Atâ-Mustafa Abdülkādir Atâ, Beyrut, 1992, s. 186; İbnü'l Esîr, el-Kâmil, X, s. 446-448; a. mlf., et-Târîhu'l-bâhir fi'd-devleti'l-Atabekiyye, nşr. Abdülkādir Ahmed Tuleymât, Kahire, 1963, s. 23; Sibt İbnü'l-Cevzî, Mir'âtü'z-zamân fî târîhi'l-a 'yân, VIII/I, Haydarabad, 1951, s. 89-90; Hüseyin Emîn, Târihu'l-Irak fì'l-asri’s-Selcûkī, Bağdat, 1965, s. 97; Köymen, a.g.e., V, s. 32-33; Gülseren Azar Nasırabadi, “Büyük Selçuklular Dönemi’nde Hemedan'ın Siyasi Tarihi”, Selçuk Üniversitesi Selçuklu Araştırmaları Dergisi (USAD), sayı 12, Bahar 2020, s. 231.

24 İbnü'l-Esîr, el-Kâmil, X, s. 446; Alptekin, “Irak Selçukluları”, DGBİT, VII, s. 296.

25 Köymen, a.g.e., V, s. 37. 
beys'i sükûnete davet ettiyse de bu teşebbüsü fayda vermedi. ${ }^{26}$ Dübeys b. Sadaka halifeyi Sultan Mahmûd'u Bağdat'a davet ettiği için kızgınlıkla tehdit ediyor, Müsterşid Billâh ise sultanı geri çevirmenin imkânsız olduğunu, artık Irak Selçuklu hükümdarının yola çıktığını söyleyerek ona sultanın huzuruna sulh yaparak beraberce çıkmalarını teklif ediyordu. ${ }^{27}$ Sultan Mahmûd öncelikle barış yoluyla meseleyi çözmeye çalıştıysa da muvaffak olamadı. Dübeys b. Sadaka, Sultan Mahmûd'un gönderdiği elçiye iltifat etmedi ancak sultanın Bağdat'a yaklaşması üzerine kuşatmayı kaldırarak Hille'ye geri dönmeye mecbur kaldı. Sultanın bu iyi niyetli girişiminden sonra bu defa da Dübeys'in Irak Selçuklu hükümdarıyla uzlaşma yolları aradığı görülmektedir. Şöyle ki; Sultan Mahmûd Bağdat'a gelince Dübeys b. Sadaka, Amîdüddevle b. Cehîr adlı Arap emîrinin kızı olan hanımını şefâat için 20.000 dinar ve kıymetli atlarla birlikte sultanın huzuruna yollayarak af dilemişse de Sultan Mahmûd kendisine ulaşmış olan miktardan hoşnut olmadı, gönderilenlerin artırılmasını talep etti. Dübeys b. Sadaka ise elinden ancak bu kadarının geldiğini ve daha fazla ödemeye gücünün yetemeyeceğini dile getirdi. ${ }^{28}$ İbnü'l-Esîr, Dübeys b. Sadaka'nın hanımını çok miktarda para ve değerli hediyelerle sultanın huzuruna göndererek af dilediği hâlde isteklerinin tek bir şartla kabul edilmediğini rivayet etmiştir. Ancak bu şartın ne olduğu hususunda mâlûmat vermemiştir. Dübeys'in söz konusu şartı reddetmekte inat etmesi sebebiyle iki tarafın uzlaşamadığı ve bunun üzerine Dübeys ile adamlarının Sultan Mahmûd'a ait otlaktaki hayvanları yağmaladıklarını zikretmiştir. ${ }^{29}$

Sultan Mahmûd 514 yılı Şevval ayında (Aralık 1120-Ocak 1121) Dübeys'in hâkim olduğu Hille'ye yürümek maksadıyla Bağdat'tan ayrıldı. Sultanın böylesine kalabalık kuvvetlerle üzerine yürüyeceğini beklemeyen Dübeys b. Sadaka zaman kazanmak üzere emân talebinde bulundu. İsteği kabul edilip Sultan Mahmûd harekâtını durdurduğunda ise haremini ve servetini Batîha'ya ${ }^{30}$ göndererek ağırlıklarını yanına aldı ve aynı zamanda kayınpederi olan Mardin Artuklu Emîri Nec-

26 İbnü'l-Esîr, el-Kâmil, X, s. 448; İbn Kesîr, a.g.e., XII, s. 350, Emîn, a.g.e., s. 97; Köymen, a.g.e., V, s. 37-38; Karakuş, a.g.m., Marife, c. 18, sayı 2, s. 375. Sibt İbnü'l-Cevzî, a.g.e., VIII/I, s. 90. Dübeys'in fesatlıklarını artırdığını, nehir kenarlarındaki üzüm bağlarını gasp ettiğini, Bağdat'taki işyerlerine çokça zarar verdiğini ve halka büyük zulümlerde bulunduğunu zikretmiştir.

27 Sibt İbnü'l-Cevzî, a.g.e., VIII/I, s. 90.

28 İbnü'l-Cevzî, a.g.e., XVII, s. 187; Sıbt İbnü'l-Cevzî, a.g.e., VIII/I, s. 91; Zehebî, Târîhu'l-İslâm ve vefeyâtü'l-meşâhîr ve'l-a 'âm: h. 501-510, h. 511-520, nşr. Ömer Abdüsselâm Tedmürî, Beyrut, 1415/1994, s. 285.

29 el-Kâmil, X, s. 449.

30 Batîha (Batâih), Güney Irak’ta Kûfe, Vasıt ve Basra arasında Fırat ile Dicle nehirlerinin meydana getirdiği bataklık bölgedir. Bkz. Hakkı Dursun Yıldız, "Batîha", DİA, V, s. 195-196. 
meddin İlgazi'ye (500-516/1106-1122) sığınd1. ${ }^{31}$ Öte yandan Sultan Mahmûd'un Bağdat'a geldikten kısa süre sonra Dübeys meselesini hâlletmek üzere Hille'ye yürümesi onun bu meseleyi ciddiye aldığını ve henüz genç yaşına rağmen amcasının ya da çevre komşu emîrlerin herhangi bir yardımına gereksinim duymadan bu sorunu çözebilecek güçte bir sultan olduğunu göstermesi bakımından ehemmiyet arz etmektedir. Bununla beraber Sultan Mahmûd, meseleyi kesin olarak çözemese dahi Dübeys'e bir süreliğine de olsa Irak’ta tutunma imkânı tanımamıştır.

Irak Selçuklu hükümdarı Bağdat'ta kaldığı süre boyunca sulhu tesis etmiş, Dübeys b. Sadaka da bölgeden uzak oluşuyla artık ciddi bir tehlike oluşturmamaya başlamıştır. Bununla birlikte Sultan Mahmûd Bağdat'1 terk ederek Hemedan'a gitmeye niyetlendiğinde ise Müsterşid Billâh, Dübeys'in geri döneceğini düşünerek 515 (1121) yılının yazını Bağdat'ta geçirmesi yönünde sultana ricalarda bulunmuştu. Sultan çok sayıda askeri olduğunu ve onların ihtiyaçlarının giderilmesi gerektiğini belirtince Irak Selçuklu ordusunun tüm ihtiyaçlarının dört ay süreyle hilâfet tarafindan karşılanacağı söylenmişti. Zaman içinde Abbâsî Halifesi'ne halktan şikâyetler gelmeye başlamış, ekonomik sıkıntılar artmış, hazinedeki para azalmış ve yaşananlar üzerine hilâfet makamı ahâlinin ileri gelenlerinden borçlanmalara kadar gitmiştir. ${ }^{32} \mathrm{Bu}$ durum belki de halifenin ülkesinde Dübeys'e destek veren Arap taraftarları bulunduğunu düşünerek her ihtimâle karşı önlemler almaya çalıştı̆̆ını ve her ne olursa olsun hilâfetin Selçukluların gücüne ihtiyaç duyduğunu göstermektedir.

514 yılı Cemâziyelevvel ayında (Temmuz/Ağustos 1120) Gürcüler Irak Selçuklu meliklerinden Tuğrul b. Muhammed Tapar'ın da hâkimiyet sahası olan İslâm topraklarına saldırılarda bulundular. Melik Tuğrul'un yardım çağrısıyla civarda yaşayan emîrler toplanmaya başladılar. Bunlar arasında Emîr İlgazi ve Dübeys b. Sadaka da bulunmaktayd1. Urfalı Mateos, "Illgazi'nin isteğiyle Dübeys' in 10.000 kişilik bir kuvvetle çağrıya katıldı̆̆ını" kaydetmektedir. ${ }^{33}$ Emîrlerin hepsi güçlerini birleştirerek Gürcülere karşı harekete geçtiler. Büyük kuvvetlerle ilerleyen Müslümanlar Tiflis'e yaklaştıklarında Gürcülerin karşısında yenilerek geri çekilmeye başlamışlar ve müslümanlar hezimete uğradığı gibi pek çok asker de

31 İbnü'l-Esîr, Atabekiyye, s. 23; İbnü'l-Adîm, Buğyetü 't-taleb fî târîhi Haleb, Biyografilerle Selçuklular Tarihi, Selçuklularla ilgili bölümlerin Türkçe trc. Ali Sevim, Ankara, 1982, s. 140141; Ebü'l-Fidâ, el-Muhtasar, II, s. 53; İbnü'l-Verdî, a.g.e., II, s. 43; İbn Kesîr, a.g.e., XII, s. 350-351; Alptekin, "Irak Selçukluları", DGBIT, VII, s. 296.

32 İbnü’l-İmrânî, el-İnbâ 'fí târîhi'l-hulefâ, nşr. Kasım es-Sâmerrâî, Kahire, 1999, s. 213; İbnü'l-Cevzî, a.g.e., XVII, s. 192; Sibt İbnü'l-Cevzî, a.g.e., VIII/I, s. 96.

33 Vekayinâme, Urfalı Mateos Vekayinâmesi (952-1136) ve Papaz Grigor'un Zeyli (1136-1162), Türkçe trc. H. Andreasyan, Ankara, 2000, s. 268-269. 
katledilmişti. İlgazi, Dübeys ve Irak Selçuklu meliki Tuğrul ise kurtulmayı başarmışlardı. Gürcüler daha sonra geri dönerek İslâm ülkelerini istilâ edip, Tiflis’i muhasara ettiler. Hatta Tiflis halkı savaşın şiddetinden büyük sıkıntılara dûçar oldu. Muhasara 515 (1121-1122) yılına kadar devam etti ve şehir k1lıç zoruyla Gürcüler tarafından ele geçirildi. ${ }^{34}$

Halife ve sultanın kuvvetlerine karşı Emîr İlgazi’nin yanında kendisini emniyete alan Dübeys b. Sadaka çok geçmeden huzursuzluklar yaratmaya devam edecekti. Gürcü yenilgisinin ardından 515 yılında (1121-1122) İlgazi'yi teselli etmek ve sağ salim döndüğü için memnuniyetlerini iletmek üzere için kadı'l-kudât Ebü'l-Kāsım ez-Zeynebî’nin nâibi Ebû Mansûr İbrahim b. Sâlim el-Hîtî, halife ve sultanın görevlendirmesiyle Emîr İlgazi’ye elçi olarak gönderildi. Bu heyetin esas amacı ise İlgazi'nin Dübeys'i himâyesinden çıkarmasını sağlamak ve kızının da Dübeys'le olan izdivacını sonlandırmaktı. Dübeys'e yakınlık gösterilmemesini İlgazi'den bilhassa istemişlerdi. ${ }^{35}$ İlgazi evlilik akdini feshetmemekle beraber akıllıca cevaplar verip elçi vasıtasıyla itaatini sundu. Halifeye ve sultana hediyeler göndererek damadının yaptıklarından dolayı onlardan özürler diledi. ${ }^{36}$ İlgazi, halife ve sultanın isteğini ne kabul etmiş ne de reddetmiş gibi davranarak iki tarafla da arasının bozulmaması için gayret sarf etmiş görünmektedir.

Bununla beraber Dübeys b. Sadaka halifenin elçileriyle de görüşmelere başlamıştı. Nitekim çok geçmeden İlgazi'nin yanından ayrılarak Hille’ye geri dönmüş ve burada yeniden hâkimiyet kurarak Selçuklulara bağlı kuvvetleri şehirden çıkarmıştı. ${ }^{37}$ Kentte yine karışıklıklar yaşanmaya başladı ve yüzlerce insan kaçmaya çalışırken boğuldu. Hille yakınlarında Nîl'deki Selçuklu şahnesi kovulunca yaşanan gelişmeler üzerine Bağdat'ta bulunan sultan ve halife Hille üzerine harekete geçmek hususunda anlaştılar. ${ }^{38}$ Dübeys b. Sadaka her ne kadar halifenin teveccühünü kazanmaya çalışmış hatta halifenin göz yumması neticesinde Hille'de yeniden ikamet etmeye başlamış olsa da şehirde gerçekleştirdiği katliamları

34 Urfalı Mateos, a.g.e., s. 268-270; İbnü'l-Kalânisî, Zeylü Târîhi Dımaşk, nşr. H. F. Amedroz, Beyrut, 1908, s. 205; İbnü'l-Esîr, el-Kâmil, X, s. 450; İbnü'l-Adîm, a.g.e., s. 145; Abdülnâim M. Hasaneyn, Îrân ve'l-Irâk fî'l- 'asri 's-Selcûkī, Beyrut, 1982, s. 126; Murat Öztürk, Irak Selçuklu Devleti Atabegleri, İstanbul, 2019, s. 23.

35 İbnü'l-Cevzî, a.g.e., XVII, s. 197.

36 İbnü'l-Cevzî, a.g.e., XVII, s. 197; İbnü'l-Adîm, a.g.e., s. 147-148; Köymen, a.g.e., V, s. 49-50; Alptekin, "Irak Selçukluları", DGBİT, VII, s. 296.

37 Köymen, (a.g.e., V, s. 50) kaynaklarımızda sarih bir kayıt bulunmamasına rağmen Dübeys'in Hille'ye geri dönebilmesinin halifeyle karşılıklı elçilerin gidip gelmesinin yarattığı anlayış havasının doğrudan bir neticesi bulunabileceğini zikretmektedir.

38 İbnü'l-Cevzî, a.g.e., XVII, s. 197. 
hilâfet nezdinde hoş görülmemiştir. Nitekim Müsterşid Billâh Dübeys meselesinin çözümünün Selçuklularla işbirliğinden geçtiğinden anlamış olmalıdır ki, Selçuklularla yakınlaşma ve Sultan Mahmûd ile ittifak ederek hareket etme yolunu tercih etmiştir.-

Dübeys, halifeye ve sultana haber gönderip onlardan özür dilediyse de bu teşebbüsü itibar görmedi. Selçuklu kuvvetlerinin harekete geçmesi üzerine o, Hille'den geri çekilince Bağdat Şahnesi Barankuş (Yarınkuş) ez-Zekevî Hille'yi geri aldı. İki taraf arasında sadece geçit yerleri bulunan bir nehir kaldığı esnada Dübeys'in kardeşi Mansûr'u rehine olarak gönderip ardından itaat arz etmesi üzerine anlaşmaya varıldı ve sultanın askerleri beraberlerinde Mansûr'la birlikte 516 (1122-1123) y1lında Bağdat'a döndüler. ${ }^{39}$ Sultan Mahmûd bu sefere bizzat katılmasada kuvvetlerini göndermiş; bu defa da Selçuklular ile Dübeys arasında uzlaşma hâs1 olmuştu.

Nitekim halife buna razı olmamış sultan Bağdat'tan Hemedan'a gitmeye karar verdiği sırada Dübeys'ten şikâyetçi olarak onun Irak'tan tamamen uzaklaştırılmasını istemiştir. Hatta halife ile Sultan Mahmûd'un vezîri Kemâlülmülk es-Sümeyremî ${ }^{40} 15$ Muharrem 516 (26 Mart 1122) tarihinde görüşmüşler; Abbâsî Halifesi, Dübeys'in babasının katlinden dolayı intikam almak istediğini, halka karşı kin ve nefretle hareket ettiğini aktararak payitahtını emniyette görmediğini; hiç olmazsa Musul'a vâli olarak gönderilen Aksungur el-Porsukî'nin halifelik nezdinde görev yapması ve Dübeys meselesini hâlletmesi için görevlendirmesini istemiştir. ${ }^{41}$ Sultan, halifenin isteğini kabul ederek bu iş için gözde kumandanını görevlendirmiştir. İbnü'l-Esîr, yaşanılanları teyit eder şekilde Sultan Mahmûd'un Aksungur'a: "Dübeys o yöredeki şehirlere saldıracak olursa onunla savaşmasını emrettiğini" ifade eder. ${ }^{42}$

Sultan Mahmûd 516 y1lı Safer ayında (Nisan-Mayıs 1122) Bağdat'tan ayr1lınca Dübeys'in yürüttüğü faaliyetlerin şiddetlendiği haberleri geldi. Bunun üzerine halife, Aksungur el-Porsukî'nin yardımını istedi ve Aksungur, Musul'dan ileride Zengîlerin ${ }^{43}$ de kurucusu olacak büyük emîrlerden İmâdüddin Zengî ile

39 İbnü'l-Esîr, el-Kâmil, X, s. 449; İbnü'l-Adîm, a.g.e., s. 141; Kayhan, a.g.e., s. 50-51.

40 Irak Selçuklu Devleti vezirlerinden Kemâlülmülk es-Sümeyremî hakkında bkz. Pınar Kaya Tan, "Irak Selçuklu Devleti'nin Muhteris Vezîri Kemâlülmülk (Kemâleddin) es-Sümeyremî", Ortaçă̆ Tarihçiliğinde Bir Duayen Prof. Dr. Abdülkerim Özaydın'a Armağan, ed. Ebru Altan, Muharrem Kesik, Murat Öztürk, İstanbul, 2020, s. 721-732.

41 İbnü'l-Cevzî, a.g.e., XVII, s. 203.

42 el-Kâmil, X, s. 473.

43 Musul ve Halep merkez olmak üzere Doğu Anadolu ve Suriye'de hüküm süren Türk-İslâm hânedanı hakkında bkz. Halil İbrahim Gök, Musul Atabeyliği Zengiler (Musul Kolu 1146-1233), 
gelen askerleriyle birlikte Hille üzerine yürüdü. Durum üzerine bu sefer Dübeys b. Sadaka da Aksungur el-Porsukî'ye doğru hareket etti. Fırat'ın Doğu sahilinde iki taraf karşılaştılar ve cenk etmeye başladılar. Nihayetinde Aksungur, askerleri ile birlikte ağır bir mağlûbiyete uğradı. ${ }^{44}$ Diğer yandan Aksungur el-Porsukî’nin savaş alanına yakın bölgede veba salgını olduğu yönünde haberler alması üzerine henüz muharebe edemeden kuvvetleriyle birlikte kaçmak zorunda kaldığına dâir rivayetler de bulunmaktadır. ${ }^{45}$ Her ne olursa olsun Abbâsî Halifesi, Sultan Mahmûd gider gitmez Dübeys'e karşı harekâta geçmiş ve bunun için de Aksungur el-Porsukî'den yararlanma yolunu seçmiştir ancak bu ağır hezimet halifenin bütün plânlarını bozmuştur.

Dübeys b. Sadaka mücadelenin ardından yağma faaliyetlerinde bulunmayarak uzlaşma yolunu tercih etti. O, Halife el-Müsterşid'e haber yollayarak kendisine düşmanlığıyla bilinen vezir Ebû Ali b. Sadaka'yı azletmesi hâlinde hilâfet makamıyla bir antlaşma yapacağını ve ona itaat edeceğini bildirdi. Halife ise Sultan Mahmûd ile istişare gereksinimi dahi duymadan Dübeys'in teklifini kabul ederek vezirini azl ve tevkif etti. ${ }^{46}$ Dübeys, bu galibiyetten sonra, bir devlet adamıymış gibi hareket ederek yağma girişimlerinde bulunmaktan ziyade Irak Selçuklu Sultanlarının da muvafakatıyla tayin edilmiş olan ve kendi politikasına ters düşen devlet görevlilerini değiştirme yolunu tercih etmiştir. $\mathrm{O}$, artık halifeyi de kontrol eder bir noktada görünmektedir. Halife ise Selçuklu Sultanını törenlerle uğurlamasının hemen akabinde otoritesini kanıtlamak istercesine başarısız bir harekâtın tertip edilmesine sebebiyet vermiştir.

Sultan Mahmûd, Dübeys'in Aksungur'u hezimete uğrattığını ve kendisinden habersiz yapılan bu anlaşmayı haber alınca Irak'taki Selçuklu hâkimiyeti ve otoritesinin devam ettiğini gösterircesine Dübeys'in kardeşi Mansûr b. Sadaka'yı ve oğlunu tevkif edip gözlerine mil çektirdi. ${ }^{47}$ Yaşanan gelişmelerden haberdâr olan Büyük Selçuklu Sultanı Sencer de kendisine haber vermeden Dübeys ile uzlaşan halifeye karşı tedbir olarak ${ }^{48}$ yeğeni Mahmûd'a elçi olarak Kadı Ebû Sa'd el-He-

Ankara, 2013; S. Heidemann, “Zangids”, El², XI, s. 452-455; Gülay Öğün Bezer, “Zengîler”, DIA, XLIV, s. 268-272.

44 Azîmî, (a.g.e., s. 53) Aksungur'un yendiğini kaydetmiştir. İbnü’l-Cevzî, a.g.e., XVII, s. 204205; İbnü'l-Esîr, el-Kâmil, X, s. 473; Zehebî, a.g.e., s. 292; İbn Kesîr, a.g.e., XII, s. 358.

45 İbnü'l-Esîr, Atabekiyye, s. 24.

46 İbnü'l-Cevzî, a.g.e., XVII, s. 205; İbnü'l-Esîr, el-Kâmil, X, s. 474; İbnü'l-Adîm, a.g.e., s. 141; Alptekin, "Irak Selçukluları", DGBIT, VII, s. 297-298.

47 İbnü'l-Esîr, el-Kâmil, X, s. 474.

48 Kayhan, a.g.e., s. 53. 
revî’yi ${ }^{49}$ gönderdi ve boşalan halifelik vezirliğine Ahmed b. Nizâmülmülk'ü tayin etmesini istedi. Mahmûd, halifeye Sultan Sencer'in arzusunu iletince yeni vezir tayin edilmiş oldu ${ }^{50}$ ve Selçukluların halifelik üzerindeki nüfuzu bir kere daha görülmüş oldu. Dübeys ise böyle bir tayinin yapılmasından dolayı mesul tuttuğu halifeyi anlaşmaya muhalefet etmekle suçlayarak yeniden Bağdat ve çevresine saldırılarda bulunmaya, şehirleri yağmalamaya başladı. Ahâlinin hayvanlarını gasp eden ve her geçen gün faaliyetlerini şiddetlendiren Dübeys ve adamları, Vâsıt'a girmek isteyince Türkler tarafından şehre sokulmadıkları gibi üzerlerine kuvvet gönderdilerse de başarılı olamadılar. Dübeys aynı zamanda Irak Selçuklu Sultanı Mahmûd tarafından kardeşi Mansûr'un gözlerine mil çekildiğini duyunca saçını kestirip siyah matem elbiseleri giydi. Nehrülmelik'te ${ }^{51}$ halifeye ait ne kadar yer var ise yağmaladı, halka eziyet ve zulümlerde bulundu. ${ }^{52}$

Bunun üzerine Halife Müsterşid Billâh, Selçuklu kuvvetlerinden yardım istemek yerine bizzat kendisi harekete geçerek ordusunun Dübeys'e karşı savaşması$\mathrm{n} 1$ emretmiştir. Bu husus halifenin dünyevî hâkimiyetini eline aldığını göstermesi bakımından dikkat çekicidir. Nitekim sonraki dönemlerde de halifeler bu defa Irak Selçuklu Devleti Sultanlarına karşı benzer bir siyaset uygulayacaklardır. ${ }^{53}$ Kalabalık hilâfet kuvvetleri Nehrülmelik yakınlarındaki Hadîse'de 4 Muharrem 517 (4 Mart 1123) tarihinde karargâh kurdular. Halifenin kendisi de bu mücadeleye bizzat katılacak, orduyu da Aksungur el-Porsukî teçhiz edecekti. ${ }^{54}$ Abbâsî Halifesi'nin önünde duacılar ve kurrâlar yer almışlardı. Dübeys'in ön tarafinda ise köle kadınlar, eğilip bükülerek def ve diğer musikî aletlerini çalan erkekler bulunuyorlard1. ${ }^{55}$ İbnü'l-Kalânisî (ö. 555/1160), Halife Müsterşid Billâh'a karş1 muhalefet içinde olduğu, isyan ettiği ve civarda bozgunculuk yaptığ 1 için Abbâsî Halifesi'nin Dübeys b. Sadaka üzerine yürüdüğünü kaydeder. ${ }^{56}$ Dübeys bu ittifak1

49 Ebû Sa‘d el-Herevî’nin hayatı ve faaliyetleri hakkında bkz. Murat Öztürk, "Bilâdü’ş-Şâm'daki Haçlı Tehlikesine Karşı Sesini Duyuramayan Kadı, Âlim, "Sefir: Ebû Sa‘d el-Herevî”, USAD, say1 11, Güz 2019, s. 153-170.

50 İbnü'l-Cevzî, a.g.e., XVII, s. 206; Zehebî, a.g.e., s. 293; Köymen, a.g.e., V, s. 59; Alptekin, "Irak Selçukluları", DGBİT, VII, s. 298; Öztürk, a.g.m., USAD, say1 11, s. 164.

51 Sarsar Kanalı'nın yakınındaki bu bölge için bkz. Yâkūt el-Hamevî, a.g.e., V, s. 324; Ebü'l-Fidâ, Takvîmü'l-büldân, s. 254; G. Le Strange, Doğu Hilafetinin Memleketleri, Türkçe trc. Adnan Eskikurt-Cengiz Tomar, İstanbul, 2015, s. 104-105.

52 İbnü'l-Esîr, el-Kâmil, X, s. 474-475; İbnü'l-Adîm, a.g.e., s. 141-142; İbn Kesîr, a.g.e., XII, s. 358.

53 Köymen, a.g.e., V, s. 62.

54 İbnü'l-Cevzî, a.g.e., XVII, s. 216; Zehebî, a.g.e., s. 297.

55 İbnü'l-Adîm, a.g.e., s. 142; İbn Kesîr, a.g.e., XII, s. 358.

56 Zeylü Târîhi Dımaşk, s. 208, 209. 
haber alınca halifeye elçi göndererek merhamet dilemiş ve rızasını talep etmişse de Müsterşid Billâh onun bu isteğini kabul etmedi. Aksungur el-Porsukî ve diğer emîrlerin sadakat sözü vererek mevzilerini almasıyla şiddetli mücadeleler yaşand1. Dübeys'in kuvvetleri 10.000 süvari ve 12.000 piyade iken, Porsukî'nin askerleri 8.000 süvari ve 5.000 piyadeden müteşekkil idi. Halife savaşın kızıştığını görünce bizzat kı1ıcını çekmişti. İmâdüddin Zengî’nin kuvvetleri de bu muharebede yer almış ve Dübeys' in önemli adamlarını ele geçirmişlerdi. ${ }^{57}$ Ancak Halife, Dübeys'i yakalayıp bu meseleyi tamamen çözmekte muvaffak olamamış ve vuku bulan savaşın akabinde Bağdat'a geri dönmüştür.

Dübeys b. Sadaka çok ağır bir hezimete uğramış hanımları, cariyeleri, birçok kumandanı ve askeri esir düşmüştü. Kendisi ise kaçıp kurtulmuştu. O, süvarileri geride bırakarak Fırat'ı geçip çöllere doğru ilerledi ve Arap kavimleriyle irtibat kurmaya çalıştı. Bunlardan Guzeyye'de bulunan Araplar, sultan ile halifeyi kızdırmak istemediler. Dübeys, Benî Müntefik Kabilesi’yle Basra üzerine yürüyüp şehri almak hususunda anlaşıp Basra'ya girdi ve çarşıları yağmaladı. Karşı çıkanlar ise katledildiler. ${ }^{58}$ Bunu duyan halife, Aksungur el-Porsukî'ye haber göndererek Dübeys meselesini ihmâl ettiği için onu kınadı. Durum üzerine Aksungur, Dübeys b. Sadaka üzerine yürümeye hazırlandı. Basra'yı tahrip eden Dübeys bu haberi alınca çöl yolunu takip ederek Ca‘ber Kalesi’ne kaçtı. O, daha önce de yardımlarını gördüğü aynı zamanda da dünür olarak aralarında iyi ilişkiler bulunduğu rivayet edilen Mâlik b. Sâlim b. Mâlik'in himâyesine girdi. ${ }^{59}$

Dübeys'in Haçlılarla da ittifak hâlinde olduğu da vâkidir. O, Haçlı komutanlarıyla ittifak ederek Haleb'i muhasara etti ve onları Haleb'i almaya teşvik etti; fakat komutanlar bunu başaramadılar ve şehrin önünden ayrılmak zorunda kaldılar. Haçlılar ile ittifak etmesine rağmen başarı elde edemeyen Dübeys sonrasında Hıristiyan müttefiklerinden ayrılıp Irak Selçuklu Meliki Tuğrul'a sığındı. Dübeys b. Sadaka, Melik Tuğrul'u Irak'a yürümesi hususunda teşvik ediyordu.$^{60}$ Amaçlarına ulaşmak için her yolu mübah sayan Dübeys, bu defa da hem Irak Selçuklu Sultanı hem de halifeye karşı yine bir Selçuklu melikini kışkırtarak isyana teşvik etme teşebbüsüne girişmiştir. Kaynaklarda Melik Tuğrul'un sultan olması hâlinde Dübeys'in ne gibi kazanımlar elde edeceği veyahut aralarında herhangi bir anlaşmanın gerçekleşip gerçekleşmediğine dair herhangi bir mâlûmata rastlamak mümkün olmamıştır.

57 İbnü'l-Esîr, el-Kâmil, X, s. 481-482; İbnü'l-Adîm, a.g.e., s. 142.

58 İbn Kesîr, a.g.e., XII, s. 358; Emîn, a.g.e., s. 98.

59 Sibt İbnü'l-Cevzî, a.g.e., VIII/I, s. 91.

60 İbnü'l-Esîr, el-Kâmil, X, s. 482; İbn Kesîr, a.g.e., XII, s. 358; Selim Kaya, "Büyük Selçuklular Döneminde Bağdat”, Akademik Bakış, sayı 15, 2008, s. 46. 
Melik Tuğrul, Dübeys ile beraber Irak'a doğru hareket etti ve çok sayıda askerle Dakûkā'ya ${ }^{61}$ vardı. Bihrûz el-Hâdim, Tekrît'den halifeye mektup yazarak Dübeys ile Melik Tuğrul hakkında bilgi verdi. Bunu duyan halife derhâl onların üzerine yürümek ve Irak'a girmelerine engel olmak için harekete geçti. Halife bu esnada Aksungur el-Porsukî'nin yerine yeni tayin edilmiş olan Irak Şahnesi Barankuş ez-Zekevî'ye de savaşa hazır olması ve asker toplaması için haber gönderdi. Böylece piyadeler ve Bağdat halkı hariç askerlerin sayıs1 12.000'i bulan hilâfetin alayı da 5 Safer 519 (13 Mart 1125) tarihinde yola çıktı. Halife, veziri ve diğer devlet erkânıyla birlikte üzerinde halifelik nişânelerini barındıran kıyafetleri, elinde asâsı ve başında çetriyle ${ }^{62}$ Şemmâsiye ${ }^{63}$ bölgesine kadar ilerledi. Burada bir müddet çadırlarında dinlenerek seyirlerine devam ettiler. 9 Safer 519'da (17 Mart 1125) Melik Tuğrul ve Dübeys de Bağdat yakınlarına kadar ilerlemişlerdi. Onlar, halifenin savaş hazırlığında olduğunu öğrenince yollarını değiştirdiler. Irak Selçuklu Meliki'nin ordusu peşi sıra talihsizlikler yaşamaya başladı ve Tuğrul şiddetli bir hummâya yakalandı. Ayrıca üzerlerine benzeri görülmemiş şiddette yağmur yağdı. Sular taştı, seller aktı. Yanlarında ne çadır ne yemek ne de hayvanları için ot bulunuyordu, tamamen hazırlıksız yakalanmışlardı. Bu sebeplerden dolayı yenileceğini anlayan Dübeys ve Tuğrul muharebeyi göze alamayarak geri dönmek zorunda kalmışlardı. ${ }^{64}$ Dübeys ise bu zor koşullarda adamlarına: "Giyinin, karnınızı doyurun ve ganimetleri alın!" diye emrederek; halife için hazırlanmış, yükü elbise ve yemek olan kafileye hücum edip mallarını gasp etti. ${ }^{65}$ Muharebeden önce Büyük Sultan'1n arzusu üzerine Irak Selçuklu Sultanı Mahmûd, veziri Osmân b. Nizâmülmülk'ü azletmişti. Azledilen vezirle kardeş olmaları hasebiyle Halife el-Müsterşid de sultanın isteğiyle vezirlik makamına getirdiği Ahmed b. Nizâmülmülk'ü azledip yerine eski veziri Ebû Ali b. Sadaka'yı bir kere daha tayin etmişti. Dübeys b. Sadaka ve Tuğrul'un teşebbüsleri başarısız olunca halifenin yeni vezîri bağışlanmak isteyen Dübeys'e merhamet göstermemesini Müsterşid Billâh'tan özellikle istedi. ${ }^{66}$

61 Bağdat-Erbil arasındaki yerleşim yeri için bkz. Yâkūt el-Hamevî, a.g.e., II, s. 459; Strange, a.g.e., s. 132.

62 Hükümdar sefere ya da alayla bir yere giderken başı üzerine açılan saltanat şemsiyesi ve hükümdarlık alâmetlerinden biridir. Bkz. C. E. Bosworth vd., "Mizalla”, El², VII, s. 191-195; Aydın Taneri, "Çetr", DIAA, VIII, s. 293-294.

63 Bağdat'ın doğusunda yer alan mahalle için bkz. Yâkūt el-Hamevî, a.g.e., III, s. 361; Strange, a.g.e., s. $61-62,83$.

64 İbnü'l-Cevzî, a.g.e., XVII, s. 228-229; İbnü'l-Esîr, el-Kâmil, X, s. 495-496; a. mlf., Atabekiyye, s. 25-26.

65 İbnü'l-Cevzî, a.g.e., XVII, s. 229.

66 İbnü'l-Cevzî, a.g.e., XVII, s. 220, 229; İbnü'l-Esîr, el-Kâmil, X, s. 496. 
En nihayetinde Dübeys ve Tuğrul çareyi Sultan Sencer'in yanına sığınmakta gördüler. Hatta giderken Hemedan'a uğrayıp halktan çok miktarda haraç ald1lar; haracı aldıktan sonra da o bölgede kayıplara karıştılar. Sultan Mahmûd bu haberi duyunca süratle onların üzerine yürüdüyse de kaçmayı başardılar. Melik Tuğrul'un Irak Selçuklu hükümdarı Mahmûd'un payitahtı konumunda bulunan Hemedan'1 yağmalama cesareti göstermesi hem hânedan üyesi olmasının verdiği hakla sultana isyan ettiğini hem de yağmacılık faaliyetlerini eylemlerinde sıklıkla kullanan Dübeys'in etkisi ve kontrolü altında olduğunu gösterir niteliktedir.

Dübeys b. Sadaka ve Melik Tuğrul Horasan'a Sultan Sencer'in yanına giderek Barankuş ez-Zekevî'den ve Sultan Mahmûd'dan şikâyetçi oldular. ${ }^{67}$ Sultan Sencer onları ağırlayıp sükûnetle dinlemekle beraber olayların müsebbibi olarak gördüğü Dübeys'i tevkif ettirdi. Ancak Irak Selçuklu Devleti ve halifelik cephesinden de haberler almayı ihmâl etmedi. Zaman içerisinde halifenin ordu toplad1ğ1 bilgisini öğrendi ve yeğeni Mahmûd'un halifeyle uzlaşmış olma ihtimâli Büyük Sultan'ı huzursuz etti. Bağdat'tan aldığı haberlerden hoşnut olmayan Sultan Sencer meselelerden daha fazla uzak kalmak istemeyerek Dübeys ve Tuğrul'la beraber Selçuklu ülkesinin batısına doğru harekete geçti. Dübeys b. Sadaka'nın tevkif edilmesinden sonra Sultan Sencer'in yanındaki pozisyonu hakkında kaynaklarda herhangi bir mâlûmata rastlanmamış olmakla birlikte birazdan değinileceği gibi Sencer'in yeğeni Mahmûd ile görüştükten sonra ondan Dübeys'i himâyesi altına almasını istemesi ya Dübeys'in yeniden Sultan Sencer'in teveccühünü kazandığını ya da Dübeys'e ihtiyaç duyduğunu göstermektedir. ${ }^{68}$

Sencer, Rey şehrine geldiğinde Hemedan'da bulunan Mahmûd'a haber yollayarak yeğenini yanına çağırdı. Mahmûd'un "Kendisine mutî‘ mi, yoksa Dübeys'in iddia ettiği gibi itaatten ayrllip asi mi?"” olduğunu öğrenmek istiyordu. Elçi, Mahmûd'un yanına gelince, o hemen amcası Sencer'in yanına gitmek üzere hazırlandı ve yola çıktı. Sultan Mahmûd'un geldiğini gören Büyük Sultan bütün askerlerine yeğenini karşılamalarını emretti ve Mahmûd'u yanındaki tahta oturtarak ona izzet-i ikramda bulundu. Böylece Mahmûd, hakkında söylenenlerin doğru olmadığını amcasına göstermiş oldu. Halife Müsterşid Billâh da elçisi Ali b. Tırâd aracılığıyla sultandan Dübeys'i uzaklaştırmasını talep etti. Sultan elçiye hüsn-ü kabul göstererek elçi için merasim düzenledi. Ayrıca ona kıymetli hediyeler ihsan etti. ${ }^{69}$ Sultan Mahmûd 15 Zilhicce 522 (10 Aralık 1128) tarihine

67 İbnü’l-Esîr, el-Kâmil, X, s. 495-497. Krş. İbn Kesîr, a.g.e., XII, s. 365; Özaydın, “Dübeys b. Sadaka”, DIA, X, s. 14.

68 Köymen, a.g.e., V, s. 124-125.

69 İbnü'l-Cevzî, a.g.e., XVII, s. 244. 
kadar Rey'de amcası Sencer'in yanında kaldı. İki taraf arasındaki görüşmelerin ise 521 (1127) yılının sonlarından itibaren başladığ 1 düşünülmektedir. ${ }^{70}$ Sultan Sencer, Aksungur el-Porsukî'nin öldürülmesinden sonra ${ }^{71}$ Musul başta olmak üzere yukarı Mezopotamya bölgesini idâre etmek üzere görevlendirilen Selçuklu hânedanına bağlı nüfuz sahibi emîrlerden İmâdüddin Zengî'nin yerine Dübeys b. Sadaka'nın Musul'a tayin edilmesini isteyerek, yeğeninden Dübeys'e iyi davranmasını istedi. ${ }^{72}$ Sultan Sencer, Dübeys'i Sultan Mahmûd'a teslim ederek Horasan'a döndükten sonra içine düştügü güç durumu gören Mahmûd, Bağdat'a giderek Sultan Sencer'in isteğini halifeye iletmeye karar verdi. Bağdat'ta Dübeys'e karşı herhangi bir tepkinin oluşmaması için şehre ayrı zamanlarda girmeye karar verildi. Sultan Mahmûd 9 Muharrem 523 (2 Ocak 1129) tarihinde Bağdat'a gelmişti. Dübeys ise üç gün sonra kente ulaşt1. İbnü’l-Cevzî (ö. 597/1201), “Dicle Nehri üzerinde seyran eden gemiler üstünde sultanın tören alayının geçtiğini, halkın bu töreni hayretle izlediğini, hatta geçen gemilere doğru halife ve sultan için dualarla karşılık verirken; Dübeys içinse lanet nidâlarıyla haykırdıklarını!" zikretmiştir. $^{73}$ Halife, ilk önce ezeli düşmanı Dübeys ile anlaşmak istememiş fakat Dübeys'in Bağdat'a gelerek Sultan Mahmûd'un misafiri olmasına da ses ç1karmamıştı. Ancak o, Musul'a Dübeys' in tayin edilmesine şiddetle karşı çıktı. ${ }^{74}$

Atabeg Zengî, sultanın Dübeys'i Musul'a vâli tayin etmek istediğini anlayınca çok kıymetli hediyeler ile birlikte Sultan Mahmûd'un ve halifenin yanına geldi. Hatta sultana 100.000 dinar ödeyeceğini söyledi. Bağdat'ta üç gün kalan Zengî, sultanın iltifatına mazhar oldu. Sultan Mahmûd, Dübeys'in tayinini durdurdu ve Atabeg Zengî Musul'a geri döndü. ${ }^{75}$ Sultan Mahmûd, Emîr Bihrûz'u Hille vâliliği dâhil olmak üzere Bağdat şahneliğine görevlendirdikten sonra Dübeys b. Sadaka'yı da yanına alarak Hemedan'a gitti. ${ }^{76}$ Böylece Dübeys hiçbir kazanç elde

70 İbnü'l-Esîr, el-Kâmil, X, s. 515. Görüşmelerin hangi tarihlerde yapıldığı hususunda bkz. Köymen, a.g.e., V, s. 118-120.

71 Sultan Muhammed Tapar döneminden beri meşhur emîrlerden Aksungur el-Porsukî 520 (1126) yılında Musul'da Câmi-i Atîk'te Cuma namazında iken Bâtınîler tarafından öldürülmüştür. Bkz. İbnü'l-Esîr, el-Kâmil, X, s. 501; Piyadeoğlu, a.g.e., s. 112-113; Coşkun Alptekin, “Aksungur el-Porsukī”, DIA, II, s. 297.

72 İbnü’l-Cevzî, a.g.e., XVII, s. 249; Alptekin, “Irak Selçukluları”, DGBİT, VII, s. 300; Özaydın, "Dübeys b. Sadaka", DİA, X, s. 14.

73 el-Muntazam, XVII, s. 253.

74 İbn Kesîr, a.g.e., XII, s. 372.

75 İbnü'l-Esîr, el-Kâmil, X, s. 517; İbnü'l-İbrî (Barhebraeus), Abû'l-Farac Tarihi, Türkçe trc. Ömer Rıza Doğrul, II, Ankara, 1950, s. 361; İ̉n Kesîr, a.g.e., XII, s. 372; Özaydın, "Dübeys b. Sadaka", DIA, X, s. 14.

76 İbnü'l-Cevzî, a.g.e., XVII, s. 253; İbnü'l-Esîr, el-Kâmil, X, s. 517; Alptekin, "Irak Selçuklular1", DGBIT, VII, s. 300. 
edememiş hatta kendi memleketine bile tayin olamamıştı. Dübeys gibi hırslı bir şahsiyet bu durumda boş durmayacak gerek halifeliğe gerek Selçuklulara tahribat veren mücadelesini devam ettirecekti.

Bu esnada Sultan Mahmûd'un hanımı vefat etti. Bu hatun, Sultan Sencer'in k1zı olup Dübeys'in durumuyla ilgilenir ve onu müdâfaa ederdi. Hatunun ölümüyle Dübeys kendisini iyiden iyiye savunması hissetti. Hatta İbnü'l-Cevzî, Sultan Sencer'in Dübeys'i Sultan Mahmûd ile evlendirdiği kızına teslim ettiğini ve hatunun Bağdat halkı tarafından Dübeys'in ağır şekilde tahkir edilmesini engellediğini de zikretmiştir. ${ }^{77}$ Daha sonra sultan da şiddetli bir hastalığa yakalandı. Bunun üzerine Dübeys b. Sadaka serbest kalma imkânı bularak Mahmûd'un küçük bir oğlunu da yanına alıp eski payitahtı Hille'ye doğru yola koyuldu. Halife Müsterşid Billâh bunu duyunca asker toplamaya başladı. Bağdat şahneliğine ilâve olarak Hille'yi de iktâ olarak alan Bihrûz ise derhâl şehirden firar etti. ${ }^{78}$ Selçuklu Şahnesi'nin Dübeys'in yaklaştığını anlayınca Hille'yi terk etmesi Dübeys'in hâlen ne kadar nüfuz sahibi olduğunu ve kendisinden bir o kadar da çekinildiğini göstermektedir.

Dübeys b. Sadaka, 523 yılı Ramazan ayında (Ağustos-Eylül 1129) Hille’ye girdi ve el-Müsterşid'in askerlerine hücum etti. Öte yandan hastalığg sebebiyle hadiselerden geç haberdâr olan Sultan Mahmûd tekrar sıhhatine kavuşunca derhâl Dübeys üzerine asker sevk etmişti. Emîr Ahmedîlî (ö. 527/1133) ${ }^{79}$ Dübeys' in yaptığı fenalıklara mâni olmak ve onu sultanın yanına getirmek üzere harekete geçtiyse de başarılı olamad1. ${ }^{80}$ Dübeys hemen halifeye ve Sultan Mahmûd'a elçi göndererek onlardan merhamet diledi. Bu meseleyle ilgili olarak elçiler gidip gelirken Dübeys bir yandan para ve asker toplamaya başladı. Sultan Mahmûd, Dübeys'in kendisine para göndermesini kabul etmedi. 523 yılı Zilkade ayında (Ekim-Kasım 1129) Bağdat'a vardı ve zor kullanarak Dübeys'i Hille'den çıkarmak üzere bu defa Emîr Kızıl'ın kuvvetlerini onun üzerine gönderdi. Dübeys, sultanın Bağdat'a geldiğini kesin olarak haber aldığında önce çöle çekilmeyi uygun gördü daha sonra Basra'ya girip çok miktarda mal aldı; halife ve sultana ait oradaki gelirlere el koydu. Bunun üzerine sultan onun ardından 10.000 süvari gönderdi. Dübeys b. Sadaka, bu kalabalık kuvvetlerle baş edemeyeceğini anla-

77 el-Muntazam, XVII, s. 253. Krş. İbnü'l-Esîr, el-Kâmil, X, s. 517.

78 İbnü'l-Cevzî, a.g.e., XVII, s. 253; İbnü'l-Adîm, a.g.e., s. 143; Köymen, a.g.e., V, s. 142.

79 Sultan Mahmûd tarafindan oğlu Dâvud'a atabeg olarak tayin edilen Emîr Aksungur el-Ahmedîlî hakkında bkz. Öztürk, Irak Selçuklu Devleti Atabegleri, s. 35-42.

80 Öztürk, Irak Selçuklu Devleti Atabegleri, s. 37; Abdülkerim Özaydın, “Ahmedîlîler”, DİA, II, s. 168. 
yarak Basra'dan ayrıldı ve yeniden çöllere gitti. ${ }^{81}$ Hadiseleri takip eden Sultan Sencer olaylardan yeğenini sorumlu tutarak Dübeys'i Musul'a tayin etmeyen Mahmûd'un, bağımsız bir sultan gibi hareket etmesine kızdı. Sultan Sencer, daha önce Mahmûd'un sultanlığına itiraz ederek zorluklar çıkaran Rey görüşmesinin ardından beraberinde Horasan'a götürdügü diğer yeğeni Melik Mes ‘ûd'u taht mücadelesine girişmesi amacıyla serbest bıraktı. Amcasının desteğini alan Melik Mes'ûd, hiç vakit kaybetmeden asker toplamaya başlamış ve kardeşi Sultan Mahmûd'la mücadele etmek üzere sefer hazırlıklarına girişmişti. Bu haberler Bağdat'a 525 yılı Rebîülevvel'inde (Şubat-Mart 1131) ulaştığında Mahmûd hazırlık yapmak ve tahtını korumak üzere Bağdat'tan ayrılmaya karar vermişti. ${ }^{82}$ Sultan Mahmûd hem Dübeys'i yakalamak hususunda muvaffak olamamıştı hem de üstüne kardeşiyle mücadele etmek durumunda kalacaktı.

Bir süre çöllerde kalan Dübeys, Suriye tarafında çok az bir kuvvetle develer üzerinde kaçarak Sermin'e vard1 ${ }^{83}$ Buradan Ca'ber Kalesi'ne gelip yanında rehin olarak bulunan Sultan Mahmûd'un küçük oğlunu kalenin hâkimine teslim ettikten sonra daha önceden yaptığ 1 gibi yine Haçlilarla temasa geçtiyse bile onlardan yeterli ilgiyi görmedi. ${ }^{84}$ Kısa süre önce ölen Sarhad ${ }^{85}$ Vâlisi Gümüştekin'in dul hanımından evlenme teklifi aldı ve bu durum üzerine Irak topraklarından Suriye'ye doğru hareket etti. Ancak kılavuzlar Dımaşk civarında yolu şaşırdılar. ${ }^{86}$ Dübeys de bunun üzerine Dımaşk hâkimi Tâcü’l-Mülûk Böri'ye ${ }^{87}$ (ö. 526/1132) 525 y1lı Şâban ayında (Haziran-Temmuz 1131) esir düştü.

Halife Müsterşid Billâh, Dübeys b. Sadaka'nın Dımaşk’ta esir düştüğünü öğrenince Tâcü'l-Mülûk Böri'ye haber gönderip Dübeys'i kendi adamlarına teslim

81 İbnü'l-Esîr, el-Kâmil, X, s. 518.

82 İbnü’l-Esîr, el-Kâmil, X, s. 520; Köymen, a.g.e., V, s. 164; Alptekin, “Irak Selçukluları”, DGBIT, VII, s. 301.

83 İbnü'l-Adîm, a.g.e., s. 144.

84 İbnü'l-Adîm, a.g.e., s. 144; Köymen, a.g.e., V, s. 170-171; Kayhan, a.g.e., s. 79.

85 Dımaşk beldelerinden Havran'a bağlı bir bölgedir ve muhkem bir kaleye sahiptir. Bkz. Yâkūt el-Hamevî, a.g.e., III, s. 401.

86 İbnü'l-Kalânisî, (a.g.e., s. 230-231) evlilik hadisesinden bahsetmemekle birlikte kılavuzların hataları yüzünden Dübeys'in yolu şaşırarak Tâcü'l-Mülûk tarafindan yakalandığını belirtir. İbnü'l Adîm ise (a.g.e., s. 144) Dübeys'in yolda iken Sarhad Kalesi sahibesinin bir başkasi ile evlilik haberini alınca Dımaşk'ta Tâcü'l-Mülûk'ün yanında bulunan Ahî Mer'i'nin obasına gittiğini; Tuğtegin'in bu haberi aldığında Ahî Mer'i ile bir ziyafet tertip etmesi ve bu esnada Dübeys'in yakalanması yönünde anlaştığını zikreder. Krş. İbn Kesîr, a.g.e., XII, s. 376.

87 Haçlılara ve Bâtınîlere karşı başarılı mücadeleler veren Dımaşk Atabegi hakkında bkz. Coşkun Alptekin, Dimaşk Atabegliği (Tog-Teginliler), İstanbul, 1985, s. 87-98; a. mlf., "Böri”, DİA, VI, s. 326-327. 
etmesini istedi. Siyasî hâkimiyetini giderek genişleten ve öteden beri Dübeys'le anlaşmazlıklar yaşamış olan Musul Atabegi Zengî, Dübeys'in el-Müsterşid'e teslim edileceğini öğrenince Böri’ye mektup yazarak Hille Emîri'ni kendisine teslim ederse yanında esir bulunan oğlu Sevinç ve beraberindeki kumandanlarını serbest bırakacağını; şayet teslim etmezse de Dımaşk'a yürüyerek şehri muhasara edeceğini bildirdi. Tâcü'l-Mülûk Böri mecburen ve mantiken bu isteği kabul edip Dübeys'i Musul hâkimine teslim etti. Dübeys b. Sadaka öldürüleceğine kesin gözüyle bakıyordu ki İmâdüddin Zengî onun düşündüğünün aksini yaptı ve Dübeys'e çok iyi davrandi. Dübeys'e erzak, silâh, hayvan ve hazineden diğer mallarını gönderdi, ona büyük hükümdarlara davrandığı gibi muamele etti. Dübeys, Zengî ile beraber Irak'a gidinceye kadar onun yanında kald1 ${ }^{88}$ Atabeg Zengî muhtemelen Sultan Sencer'in isteği ile Dübeys b. Sadaka'ya iyi davranmış, hürmet göstermişti.

Diğer yandan 15 Şevval 525 (10 Eylül 1131) tarihinde Irak Selçuklu Sultanı Mahmûd hastalanarak vefat etti. Sultan Mahmûd'un ölümü üzerine Irak Selçuklularında hâkimiyet mücadeleleri yeniden yaşanmaya başladı. Nitekim babasının ardından hükümdar ilân edilen Dâvud b. Mahmûd'un sultanlığına amcaları karşı çıkıyorlardı ve halife de kendilerine destek vermekte idi. Yaşanan mücadelelerin neticesinde Sultan Sencer olaylara müdâhale etmek durumunda kaldı ve yeğenleriyle mücadele ederek I. Tuğrul b. Muhammed Tapar'1 (526-529/1132-1134) tahta çıkardı. Dübeys b. Sadaka, Sultan Mahmûd'un vefatından sonra da hem Abbâsî Hilâfeti hem de Irak Selçuklu Sultanları ve melikleriyle mücadelelerde bulunmaya devam etmişse de nihayetinde Mes'ûd'un (529-547/1134-1152) saltanat döneminde bizzat onun emriyle öldürülmüştür.

Bu çalışmada Dübeys b. Sadaka'nın yalnızca Sultan Mahmûd devrindeki faaliyetleri ele alınmıştır. ${ }^{89}$ Dübeys'in Mahmûd'un hükümdarlığını hiç istemediği; başta Hille olmak üzere Irak’1 kendi nüfuzu altına almayı amaç edindiği ve Irak Selçuklu Devleti Sultanı'nın aynı coğrafyada otorite tesis etmesinden büyük rahatsızlık duyduğu görülmektedir. Selçuklu melikleri arasındaki taht kavgalarından her firsatta istifade etmeye çalışan Dübeys, Sultan Mahmûd döneminde de önce Melik Mes'ûd'u ardından Melik Tuğrul'u isyana teşvik etmişse de bu

88 İbnü'l-Kalânisî, a.g.e., s. 231; İbnü'l-Cevzî, a.g.e., XVII, s. 263; İbnü'l-Esîr, el-Kâmil, X, s. 527-528; Sibt İbnü'l-Cevzî, a.g.e., VIII/I, s. 135; İbnü'l-Adîm, (a.g.e., s. 144-145) Zengî’nin 50.000 altına Dübeys'i aldığını, Halep'e getirerek saraya yerleştirdiğini ve kıymetli hil'âtlar verdiğini ifade eder.

89 Belirtmek fayda bulunmaktadır ki Hille'nin kuvvetli emîri Dübeys'in Irak Selçuklu Devleti’nin ilk sultanının vefatından sonra yürüttüğü faaliyetler hazırlamakta olduğumuz başka bir çalışmanın konusudur. 
teşebbüsleri başarıya ulaşmamıştır. Hatta Melik Tuğrul ile gerçekleştirdikleri isyan sonucunda Sultan Sencer'e sığınarak Irak'tan uzaklaşmak zorunda kalmıştır. Hilâfete ve Selçuklu Devleti'ne beslediği düşmanlığın yanı sıra kaynakların Dübeys hakkında ittifak içinde oldukları bir diğer husus yağma ve talan faaliyetleriyle ahâliye büyük zararlar vermiş olduğu gerçeğidir. Bu yağmacılık faaliyetleri ve girişimleri başta Bağdat'ta olmak üzere hâkimiyet kurmak istediği bölgelerde Dübeys'in bir lider olarak görülmesini engellemiştir. Dübeys, Büyük Selçuklu Sultanı Sencer tarafindan Abbâsî Halifesi'ni kontrol altında tutabilmek için koz olarak görülmüş ve Sultan Sencer halifelikle aynı ırktan olması, emîrliğinin sahip olduğu askerî gücü gibi sebeplerle Dübeys'i faaliyetlerinde serbest birakarak Irak Selçuklu Devleti'nde dengeleri sağlamaya çalışmıştır. Saldırılarına ve âsiliklerine rağmen hem Abbâsî Hilâfeti hem de Selçuklular Dübeys b. Sadaka ile kimi zaman müttefik olmuşlar; Dübeys de bu ittifaklar sayesinde Mezyedîlerin Irak coğrafyasındaki varlığını devam ettirme hususunda muvaffak olmuştur. 


\section{Kaynakça}

Alptekin, Coşkun, Dimaşk Atabegliği (Tog-Teginliler), İstanbul, 1985. , "Irak Selçukluları”, Doğuştan Günümüze Büyük İslâm Tarihi (DGBIT), VII, İstanbul, 1988. , “Aksungur el-Porsukî”, DİA, II. , "Böri", $D \dot{I} A, \mathrm{VI}$.

Avc1, Casim, "Medâin", DİA, XXVIII.

Azar Nasırabadi, Gülseren, “Büyük Selçuklular Dönemi’nde Hemedan'ın Siyasi Tarihi”, Selçuk Üniversitesi Selçuklu Araştırmaları Dergisi (USAD), sayı 12, Bahar 2020.

Azîmî, Târîhu'l Azîmî, Azîmî Tarihi: Selçuklularla İlgili Bölümler (H. 430538=1038/39-1043/44), nşr. Ali Sevim, Ankara, 2006.

Bosworth, C. E., vd., "Mizalla”, $E l^{2}$, VII.

Ebü'l-Fidâ, Takvîmü'l-büldân, Ebü'l-Fidâ Coğrafyası, Türkçe trc. Ramazan Şeşen, İstanbul, 2017. Mahmûd Deyyûb, II, Beyrut, 1417/1997.

Emîn, Hüseyin, Târihu'l-Irak fì'l- 'asri s-Selcûkī, Bağdat, 1965.

Gök, Halil İbrahim, Musul Atabeyliği Zengiler (Musul Kolu 1146-1233), Ankara, 2013.

Güzel, Fatih, "Selçuklulara Başkaldıran İlk Halife: Müsterşid Billah (512529/1118-1135)", Insan ve Toplum Bilimleri Araştırmaları Dergisi (İtobiad), c. 8, say1 4, 2019.

Halîl, İmâdüddin, “Irak, III. Tarih”, DİA, XIX.

Hasaneyn, Abdülnâim M., Îrân ve'l-Irâk fî̀'l- 'asri's-Selcûkī, Beyrut, 1982.

Heidemann, S., "Zangids", $E l^{2}$, XI..

İbn Havkal, Sûretü'l-ârz, X. Asır'da İslâm Coğrafyası, Türkçe trc. Ramazan Şeşen, İstanbul, 2014.

İbn Kesîr, el-Bidâye ve 'n-Nihâye, el-Bidâye ve'n-Nihâye, Büyük İslâm Tarihi, Türkçe trc. Mehmet Keskin, XII.

İbnü'l-Adîm, Buğyetü 't-taleb fî târîhi Haleb, Selçuklularla ilgili bölümlerin Türkçe trc. Ali Sevim, Ankara 1982. 
İbnü'l-Cevzî, el-Muntazam fì târîhi'l-mülûk ve'l-ümem, Biyografilerle Selçuklular Tarihi, nşr. Muhammed Abdülkādir Ahmed Atâ-Mustafa Abdülkādir Atâ, XVII, Beyrut, 1992.

İbnü'l-Esîr, el-Kâmil fi't-târih, İslâm Tarihi İbnü'l-Esîr, el-Kâmil fi't-Tarih Tercümesi, Türkçe trc. Abdülkerim Özaydın, X, İstanbul, 1987.

, et-Târîhu'l-bâhir fi'd-devleti'l-Atabekiyye, nşr. Abdülkādir Ahmed Tuleymât, Kahire, 1963.

İbnü'l-İbrî (Barhebraeus), Abû'l-Farac Tarihi, Türkçe trc. Ömer Rıza Doğrul, II, Ankara, 1950.

İbnü'l-İmrânî, el-İnbâ' fì târîhi'l-hulefâ, nşr. Kasım es-Sâmerrâî, Kahire, 1999.

İbnü’l-Kalânisî, Zeylü Târîhi Dımaşk, nşr. H. F. Amedroz, Beyrut, 1908.

İbnü'l-Verdî, Tetimmetü'l Muhtasar fì ahbâri'l-beşer, nşr. Ahmed Rif'at el-Bedrâvî, II, Beyrut, 1970.

Karakuş, Nadir, "Hille'de Bir Bedevî Emîri: Dübeys b. Sadaka", Marife, c. 18, say1 2, 2018.

Kaya, Selim, "Büyük Selçuklular Döneminde Bağdat”, Akademik Bakış, say1 $15,2008$.

Kaya Tan, Pınar, "Irak Selçuklu Devleti'nin Muhteris Vezîri Kemâlülmülk (Kemâleddin) es-Sümeyremî”, Ortaçağ Tarihçiliğinde Bir Duayen Prof. Dr. Abdülkerim Özaydın'a Armağan, ed. Ebru Altan, Muharrem Kesik, Murat Öztürk, İstanbul, 2020.

Kayhan, Hüseyin, Irak Selçukluları, Konya, 2001.

Keleş, Nevzat, "İnsanların En Kibarlarından: Selçukluların Bağdad Şahnesi Bihrûz el-Hâdim”, Tarih Incelemeleri Dergisi, c. XXX, sayı 2, 2015.

Köymen, Mehmet Altay, Büyük Selçuklu Imparatorluğu Tarihi, İkinci İmparatorluk Devri, V, Ankara, 1991.

Mallett, Alex, "The Life of Aq-Sunqur al-Bursuqi: Some Notes on Twelfth-Century Islamic History and Thirteenth-Century Muslim Historiography", Turkish Historical Review, c. 2, say1 1, 2011.

Merçil, Erdoğan, "Şahne”, DİA, XXXVIII.

Öğün Bezer, Gülay, “Zengîler”, DİA, XLIV.

Özaydın, Abdülkerim, "Büyük Selçuklularda Şahnelik Müessesesi ve 
Şahnelerin Taht Kavgalarındaki Rolü”, İsmail E. Erünsal'a Armağan, I, İstanbul, 2014.

, “Ahmedîlîler”, DiA, II.

, "Dübeys b. Sadaka", DİA, X.

, "Mezyedîler", DIA, XXIX.

Özgüdenli, Osman Gazi, "Selçuklu-Hilâfet Münasebetlerinde Bir Dönüm Noktası: Halife el-Müsterşid'in Katli Meselesi”, Tarih Dergisi, sayı 39, 2004.

, "Müsterşid-Billâh", DIA, XXXII.

Öztürk, Murat, Irak Selçuklu Devleti Atabegleri, İstanbul, 2019. , "Bilâdü'ş-Şâm'daki Haçlı Tehlikesine Karşı Sesini Duyuramayan Kadı, Âlim, Sefir: Ebû Sa‘d el-Herevî”, USAD, sayı 11, Güz 2019.

Piyadeoğlu, Cihan, "Büyük Selçuklular Döneminde Atabegler", (Yayımlanmamış Yüksek Lisans Tezi), İstanbul Üniversitesi Sosyal Bilimler Enstitüsü, İstanbul, 1999.

Sibt İbnü'l-Cevzî, Mir'âtü’z-zamân fì târîhi'l-a 'yân, VIII/I, Haydarabad, 1951.

Strange, G. Le, Doğu Hilafetinin Memleketleri, Türkçe trc. Adnan Eskikurt-Cengiz Tomar, İstanbul, 2015.

Taneri, Aydın, "Çetr", DIA, VIII.

Urfalı Mateos, Vekayinâme, Urfalı Mateos Vekayinâmesi (952-1136) ve Papaz Grigor'un Zeyli (1136-1162), Türkçe trc. H. Andreasyan, Ankara, 2000.

Yâkūt el-Hamevî, Mu 'cemü'l-büldân, nşr. Dâru Sâdır, II, Beyrut, 1397/1977.

Yıldız, Hakkı Dursun, "Batîha", DIA, V.

Zehebî, Târîhu'l-İslâm ve vefeyâtü'l-meşâhîr ve'l-a lâm: h. 501-510, h. 511520, nşr. Ömer Abdüsselâm Tedmürî, Beyrut, 1415/1994. 
